Article

\title{
The Tax Burden on Wastewater and the Protection of Water Ecosystems in EU Countries
}

\author{
Leticia Gallego Valero ${ }^{1, *}$, Encarnación Moral Pajares ${ }^{1}$ and Isabel María Román Sánchez ${ }^{2}$ \\ 1 Department of Economy, University of Jaén, 23071 Jaén, Spain; emoral@ujaen.es \\ 2 Department of Economy and Business, University of Almería, 04120 La Cañada, Spain; iroman@ual.es \\ * Correspondence: lgallego@ujaen.es; Tel.: +34-651-888-733
}

Received: 3 January 2018; Accepted: 13 January 2018; Published: 16 January 2018

\begin{abstract}
: $80 \%$ of all wastewater is discharged into the environment without first eliminating contaminants, and the consequences are cause for concern. The ecotaxes levied on effluents in many developed countries are aimed at preventing and minimizing water pollution and also, in part, helping to finance proper water reclamation facilities. The aim of this study is to conduct a comparative analysis of the current tax burden in a set of European Union countries on wastewater discharges and to assess its relationship with the quality of fresh water and other economic and political variables. The paper draws on different theoretical arguments and estimates a panel data model to verify the effectiveness of taxes in protecting aquatic ecosystems. These taxes are directly dependent on the environmental health status of water and inversely linked to the volume of discharged wastewater. In addition, a direct relationship is found between the tax burden on wastewater discharges and the variables representing the Human Development Index, the per capita expenditure on protecting water resources, the relative weight of ecotaxes in a country's total tax revenues, and public support for green political movements.
\end{abstract}

Keywords: taxes; wastewater; environmental protection; environmental performance index; public expenditure; panel data

\section{Introduction}

Water pollution is a globally important issue as it leads to the degradation of water ecosystems, with negative repercussions on productive activities and human health [1]. Worldwide, $80 \%$ of all wastewater is discharged without being treated in any way; low-income countries register the highest percentages, with an average of $92 \%$, compared to values of slightly less than $30 \%$ in their high-income counterparts. There is currently a global need for proper wastewater management, made all the more urgent by the issues of climate change and water stress [2,3] as asserted by the UN (UNGA 2015: Agenda 2030 for Sustainable Development, adopted on 25 September 2015 by the United Nations General Assembly, includes Goal 6.3: “improve water quality by reducing pollution, eliminating dumping and minimizing the release of hazardous chemicals and materials, halving the proportion of untreated wastewater and substantially increasing recycling and safe reuse globally.") and the OECD [4]. In the EU, Directive 2000/60/EC, which establishes a framework for community action, in the field of water policy, highlights in its preamble the need to "contribute to the progressive reduction in discharges of hazardous substances into water". In this regard, Article 9.1 stipulates, inter alia, that "Member States shall take account of the principle of recovery of the costs of water services, including environmental and resource costs ... in accordance with the polluter pays principle". This European legislation has driven the development and modification of provisions that regulate water-related ecotaxes in the different EU member states. Some countries, such as Germany, choose to prohibit or control the use of certain pollutants in order to stop them entering wastewater flows. They do so through regulatory, technical and/or other means, with heavy fines for failure to comply with regulations. 
The negative impact of untreated wastewater on health, the economy and the environment calls for an examination of the different aspects involved in this issue. The aim of this paper is to conduct a comparative analysis of the relative impact of taxes on wastewater discharges as an instrument to prevent or reduce pollution at source in different EU countries between 2000 and 2013. An additional aim is to identify a possible link between the tax burden on wastewater discharges and the environmental performance index relating to water, the per capita volume of wastewater discharged, the current public-sector expenditure on environmentally-beneficial actions, the relative weight of environmental taxes in the national tax structure, the level of economic and social development of the national economies, the countries' supranational commitments aimed at protecting water resources, and public support for left-wing green parties. Above all, the purpose of this paper is to establish valid arguments that can help guide the actions of both individuals and wastewater management organizations towards protecting water ecosystems.

\section{Taxes and Wastewater in EU Countries: Literature Review and Hypotheses Design}

Since the end of the 1960s, a number of European countries such as the Netherlands (in 1969), France, Denmark and Germany [5-7], have been applying different economic instruments to reduce the amount of pollutants discharged into bodies of water, improve the quality of wastewater and help protect the environment. Directive 91/271/EEC—which is the basis for all regulations in EU Member States on the treatment of urban wastewater and wastewater discharged from certain industrial sectors-and later Directive 2000/60/EC—which in Article 16 calls for the development of "specific measures against the pollution of water" taking into account the "polluter pays principle" [8-10]—call for the establishment of new taxes or the modification of existing taxes in EU countries in order to address the negative externalities of economic activity on wastewater and to ensure the polluter pays an appropriate price. Depending on the country in question, these instruments may be managed at the national, regional or municipal level [11].

Government actions to control pollution may be implemented through mandate-control-sanction instruments [12] and/or through the establishment of ecotaxes and discharge permits. The mandate-control-sanction approach requires the regulator to set a legal limit on the amount of pollutants per issuer in order to meet certain quality targets for water belonging to the public water resources. Taxes are aimed at correcting market failures, by influencing the actions of the polluting actors, who must pay for environmental costs. Environmental taxation offers important advantages over other forms of intervention [13].

In EU countries, public revenues linked to water basically come from rates and ecotaxes [14]. Rates are paid in exchange for a service provided by the administration which citizens use for their own benefit. Revenue collected through rates payment can only be used to finance the service. Ecotaxes or environmental taxes, such as the effluent control tax in Spain governed by the Water Act, are paid without any direct compensation being received in exchange; they are intended as a way of correcting a negative externality, regardless of whether or not the revenue collected is then targeted towards improvements in the natural environment [15]. Generally speaking, there may be three possible objectives for imposing an ecotax on water: to reduce the consumption of this natural resource and, at the same time, discharges; to regulate the disposal of effluents, influencing the behaviour of polluting actors; and to help finance the investment and operating costs of the infrastructures required to treat such effluents.

In the countries included in this analysis, different types of taxes and rates are applied to water and wastewater, as shown in Table 1. The first are those levied on the extraction of the resource, which generally reflect its origin and its intended use [11]. The second are those corresponding to supply, whereby the user is charged an amount based on the volume of water consumed. With respect to the third type, the taxable event is the discharge into sanitation systems, regardless of the nature of the discharge. Finally, there are the taxes that assign a monetary value to pollution. In this last case, different parameters are used to classify the degree of pollution in the water discharged, such as the 
chemical oxygen demand (COD), the presence of suspended solids (SS), conductivity (C), the biological oxygen demand (BOD), nutrient concentration-particularly nitrogen $(\mathrm{N})$ and phosphorus $(\mathrm{P})$ - heavy metals (HM), inhibitory substances (IS) and temperature difference $(\Delta \mathrm{T})[16]$.

Table 1. Rates and ecotaxes levied on water in the European Union.

\begin{tabular}{ccccc}
\hline Country & Extraction & Supply & Use and Discharge & Pollution \\
\hline Belgium & $\mathrm{E}$ & & $\mathrm{R} / \mathrm{E}$ & $\mathrm{R} / \mathrm{E}$ \\
Czeck Republic & $\mathrm{R}$ & & $\mathrm{E}$ & $\mathrm{E}$ \\
Denmark & & $\mathrm{R} / \mathrm{E}$ & $\mathrm{E}$ \\
Estonia & $\mathrm{R}$ & & $\mathrm{R}$ & $\mathrm{E}$ \\
France & $\mathrm{R}$ & $\mathrm{R}$ & $\mathrm{E}$ & $\mathrm{E}$ \\
Hungary & $\mathrm{R}$ & & $\mathrm{R}$ & $\mathrm{E}$ \\
The Netherlands & & & $\mathrm{E}$ & $\mathrm{E}$ \\
Portugal & & $\mathrm{R}$ & $\mathrm{E}$ \\
Slovak Republic & & $\mathrm{R}$ & $\mathrm{R}$ & $\mathrm{E}$ \\
Slovenia & $\mathrm{R}$ & $\mathrm{R}$ & $\mathrm{R}$ & $\mathrm{E}$ \\
Spain & $\mathrm{R}$ & $\mathrm{R}$ & $\mathrm{R}$ & $\mathrm{E}$ \\
Sweden & & & $\mathrm{R}$ & $\mathrm{E}$ \\
United Kingdom & & &
\end{tabular}

Note: R: Rate; E: Ecotax. Source: [17].

Thus, taking into account the fact that in the countries under study taxes form part of the strategy to reduce discharges and improve the quality of water ecosystems [14], and considering, as Pigou put it, the deterrent effect of ecotaxes on the polluting behaviour of economic agents [13], the following hypotheses can be proposed:

Hypothesis 1. Maintaining better health status of water resources requires a greater tax burden on wastewater.

Hypothesis 2. Reducing the volume of wastewater discharged per capita entails a higher tax burden on wastewater.

The design and implementation of an appropriate environmental policy depends on the socioeconomic and institutional conditions of the country in question [7]. Economic development is a key precondition, to ensure the country has sufficient resources to cover the investment costs, especially sunk or irrecoverable costs. As societies develop economically, citizens seek higher quality, healthier living conditions, and are willing to bear the fiscal costs associated with environmental protection [18]. In other cases, however, environmental taxes are believed to have a possible inflationary effect, acting as an indirect tariff, and negatively affecting the competitiveness of the productive structures in the countries that apply these taxes [19]. Furthermore, less stringent environmental standards can help generate growth by attracting multinational companies in highly-polluting sectors [20]. Based on the abovementioned arguments, the following hypotheses can be formulated:

Hypothesis 3. The level of socio-economic development of a country affects the tax burden on wastewater.

The WFD explicitly includes the "polluter pays principle", the use of economic instruments and the cost recovery principle $[21,22]$. These precepts have led to the modification of public prices and, in other cases, have prompted the implementation or reformulation of applicable rates and ecotaxes. In EU countries, tax revenues from charges on wastewater discharges are partly used to finance wastewater treatment systems $[11,23,24]$. These include the more advanced, more expensive third-generation systems, which require higher levels of funding for their implementation and operation [25]. Such systems enable the reclamation of wastewater to the extent that it can be reused for certain applications [26-28]. In light of the above, the following hypotheses are put forward: 
Hypothesis 4. The implementation of the Water Framework Directive has positively affected the tax burden on wastewater.

Hypothesis 5. Higher public-sector expenditure on actions to protect water ecosystems leads to a higher tax burden on wastewater.

The tax model known as "Green Tax Reform" makes environmental taxation a key part of national tax systems, incorporating new taxes directly calculated on the basis of pollutant loads [29]. One of the objectives of this scheme, in effect since the 1990s in northern European countries such as Sweden (1991), Norway (1992), Denmark (1994), the Netherlands (1995) and Finland (1997), is to establish tax types that are strictly environmental-regulatory in nature, reducing the weight of traditional direct taxation [18]. Given the above, we aim to test the possible relationship between the weight of environmental taxes in countries' tax structure and the tax burden on wastewater, as set out in the following hypothesis:

Hypothesis 6. The weight of environmental taxes in a country's tax structure is positively related to the tax burden on wastewater.

It has been shown that both economic and institutional variables are determinants of the tax burden [30,31], while social variables determine the acceptance of environmentally-driven tax increases [32,33]. In other cases, tax structures are influenced by the political leaning of the party in government [34]. Although at times there has been insufficient evidence to establish a link between the level of the municipal tax burden and the political leaning of the ruling party, [35] at other times, the greater degree of commitment to and concern for the environment that characterizes left-leaning green parties clearly translates into specific actions in defence of the natural environment, such as establishing ecotaxes to reduce pollution levels [36]. In light of these arguments, the following hypothesis is raised:

Hypothesis 7. The weight of green political parties in different national economies, reflecting social awareness of the environment, is related to the tax burden on wastewater.

\section{Data and Methodology}

The objective of our analysis is to identify potential determinants of the tax burden on water and wastewater in European countries. To that end, we carry out a detailed analysis of the relevant variables and test the relationship between the dependent and the independent variables. It should be noted that the information recorded in official statistics is, in many cases, incomplete or based on estimates, thus giving rise to biased measures of the real situation. Although the OECD databases cover the 35 member countries, the available information is not complete in all cases, with gaps for particular variables and countries. Our final sample includes data from 13 countries, for the period 2000-2013, and a panel data analysis was carried out on that sample. It is worth noting the following clarifications:

(a) The countries under study are Belgium, the Czech Republic, Denmark, Estonia, France, Hungary, the Netherlands, Portugal, the Slovak Republic, Slovenia, Spain, Sweden and the United Kingdom. For Germany, Austria, Bulgaria, Cyprus, Croatia, Finland, Greece, Italy, Poland and Romania, specific data on revenue collected from taxes on wastewater are not available but instead are included under the heading "other environmental tax revenues", together with others.

(b) The sample contains data for 14 consecutive years, covering the period 2000 to 2013. The selection of the time period under study was determined by the unavailability of data on wastewater discharges for certain countries, such as Spain, from 2013 on. 
(c) The dependent variable is the tax burden on wastewater discharges, approximated by taxes levied on water and wastewater. It only includes revenues generated through ecotaxes, and not revenues raised through rates paid by the public for the provision of extraction, supply, sanitation and treatment services, as in the case of the United Kingdom, Sweden and the Czech Republic [37,38], which may be managed by public, semi-public or private entities. The dependent variable is defined as the relationship between the tax burden levied and the tax base that generates it [32]. It is quantified by means of an average effective rate (AER), defined as the ratio between the income from the taxable event and the volume of wastewater discharged, as reflected in the following expression: AER = Tax income/discharged wastewater.

(d) The model incorporates a total of seven independent variables, the description, source and expected sign of these variables are presented in Table 2. These variables have been selected on the basis of the hypotheses set out in Section 2.

Table 2. Independent variables used in the analysis: descriptions, sources and expected relationship with the dependent variable.

\begin{tabular}{|c|c|c|c|}
\hline Variable & Description & Source & Expected Sign \\
\hline Environmental health status of water * & $\begin{array}{l}\text { Proxy used: Environmental Performance Index } \\
\text { for water }\end{array}$ & [39] & + \\
\hline Wastewater discharged per capita & $\begin{array}{l}\text { Volume of wastewater discharged in cubic } \\
\text { metres, per inhabitant and year }\end{array}$ & [40] & - \\
\hline Human Development Index & $\begin{array}{l}\text { Indicator of the level of socio-economic } \\
\text { development }\end{array}$ & [41] & + or - \\
\hline WFD implementation & $\begin{array}{l}\text { Dummy: year marking the beginning of the } \\
\text { implementation of the Water Framework } \\
\text { Directive, indicative of supranational } \\
\text { commitments }\end{array}$ & [42] & + \\
\hline Expenditure on protecting water resources & $\begin{array}{l}\text { Proxy used: per capita expenditure on the } \\
\text { environment in dollars and purchasing power } \\
\text { parities }\end{array}$ & [43] & + \\
\hline $\begin{array}{l}\text { Weight of environmental taxes in the } \\
\text { country's tax structure }\end{array}$ & $\begin{array}{l}\text { Share of tax revenues from environmental taxes } \\
\text { in total tax revenues }\end{array}$ & [43] & + \\
\hline $\begin{array}{l}\text { Social support for green political } \\
\text { movements }\end{array}$ & $\begin{array}{l}\text { Categorical variable: seats held in the } \\
\text { European Parliament by green parties of the } \\
\text { different countries in 1999, } 2004 \text { and } 2009\end{array}$ & [44] & + \\
\hline \multicolumn{4}{|c|}{$\begin{array}{l}\text { Source: own elaboration. * The data for the variable environmental health status of water are available from } 2007 ; \\
\text { data prior to that year have been estimated. The Environmental Performance Index (EPI) measures how close a } \\
\text { country is to achieving internationally-established objectives in various areas, or, if no such targets have been set, } \\
\text { how countries compare with each other. The water and sanitation index includes indicators such as population with } \\
\text { access to potable water, the conditions of sanitation infrastructures and the collection and treatment of wastewater } \\
\text { before releasing it into the environment. }\end{array}$} \\
\hline
\end{tabular}

The possible association between the tax burden on water and wastewater in the EU countries under study and the evolution of the aforementioned variables can be tested by means of the following equation:

$\operatorname{Taxb}_{i t}=\alpha_{i t}+\alpha_{1}$ EPIw $_{i t}-\alpha_{2}$ Discpc $_{i t}+\alpha_{3} \mathrm{HDI}_{\mathrm{it}}+\alpha_{4} \mathrm{WFD}_{\mathrm{it}}+\alpha_{5} \mathrm{Expc}_{\mathrm{it}}+\alpha_{6} \mathrm{Wtax}_{\mathrm{it}}+\alpha_{7} \mathrm{Grparty}_{\mathrm{it}}+\alpha_{\mathrm{it}}$ where:

$\operatorname{Taxb}_{\mathrm{it}}$ : tax burden on wastewater discharges in country $i$ at time $t$,

$E \mathrm{PI}_{\mathrm{it}}$ : environmental performance index for water and sanitation of country $i$ at time $t$

Discpc $c_{i t}$ : wastewater discharged per capita in country $i$ at time $t$

$\mathrm{HDI}_{\mathrm{it}}$ : Human Development Index for country $\mathrm{i}$ at time $\mathrm{t}$

WFD $_{i t}$ : dummy, Water Framework Directive implementation in country i at time $t$

Expc $_{\mathrm{it}}$ : per capita expenditure on environmental protection in country $\mathrm{i}$ at time $\mathrm{t}$ 
Wtax ${ }_{i t}$ : weight of environmental taxes in the national tax structure in country $i$ at time $t$

Grparty $_{\text {it: }}$ Green party seats in the European Parliament from country i at time $t$

$\alpha$ : estimated coefficients.

Finally, the constant, $\alpha_{i t}$ captures the effects of other exogenous factors that are not included in the model, and $\alpha \mathrm{e}_{\mathrm{it}}$ is the error term.

The panel data method was chosen to capture the effects of variables that have not been measured but that may explain the variation between countries. The variables are used in logarithms, formulating a series of econometric models until the best one has been identified.

The availability of time series for each of the variables and the sample units (countries), as well as the possible presence of unobserved individual effects, underline the suitability of using panel data econometric techniques. This paper employs a combination of cross-sectional and time-series analyses, since it focuses on specific units and the observations can be tracked over time, controlling for unobservable individual heterogeneity. Indeed, each country shows geographic, historical, political and economic differences, and these specific factors, which are difficult to measure, may affect the tax burden on water and wastewater. Other advantages of using this technique are that it reduces the collinearity between variables, provides more degrees of freedom and higher efficiency, enables better examination of the dynamics of adjustment, allows effects undetected by time series or cross sections to be identified and measured, enables more complex models complex to be built and tested, and it eliminates or reduces bias in results by aggregating information [45]. However, among the drawbacks, it is worth pointing out problems in the design and sourcing of data, limitations resulting from short time series and cross-sectional dependence.

\section{Results and Discussions}

\subsection{Descriptive Analysis}

We start the empirical analysis by presenting the descriptive statistics of the variables considered in our study, shown in Table 3. First of all, we should highlight the high dispersion observed in the dependent variable, the tax burden on wastewater discharges. Similarly, high dispersion can be seen on some of the independent variables, such as the seats held in the European Parliament by green parties, expenditure on protecting water resources and, to a lesser extent, wastewater discharged per capita. Less variation is observed, however, in the environmental performance index for water, with values ranging from 90.90 to 99.92 , or the HDI, which lies between 0.76 and 0.92 .

Table 3. Descriptive statistics of the tax burden on wastewater discharges and the independent variables.

\begin{tabular}{ccccccc}
\hline Variable & Observations & Mean & $\begin{array}{c}\text { Standard } \\
\text { Deviation }\end{array}$ & $\begin{array}{c}\text { Coefficient } \\
\text { of Variation }\end{array}$ & Minimum & Maximum \\
\hline Taxb & 182 & 0.23 & 0.29 & 1.26 & $9 \times 10^{-10}$ & 1.09 \\
EPIw & 182 & 98.19 & 2.14 & 0.02 & 90.90 & 99.92 \\
Discpc & 182 & 107.98 & 63.43 & 0.58 & 21.22 & 288.03 \\
HDI & 182 & 0.85 & 0.03 & 0.03 & 0.76 & 0.92 \\
WFD & 182 & 0.86 & 0.34 & 0.39 & 0 & 1 \\
Expc & 182 & 116.33 & 118.74 & 1.02 & 3.58 & 500.65 \\
Wtax & 182 & 7.37 & 1.74 & 0.23 & 4.31 & 11.27 \\
Grparty & 182 & 1.86 & 2.89 & 1.55 & 0 & 14 \\
\hline
\end{tabular}

Source: Own elaboration based on [39-44].

In the set of EU economies under study with relevant information available, there has been ongoing growth in tax revenues from water and wastewater in recent years, as shown in Figure 1. Between 2000 and 2013, the total amount collected in taxes aimed at preventing or reducing pollution at source, in terms of pollution load and/or volume of wastewater produced, shows a cumulative 
average annual growth rate of $4.83 \%$, with annual variations of more than $20 \%$ in 2003 and 2008 . As a result, the total value of these tax revenues is 1.84 times greater by the end of this 13 -year period. This evolution, however, does not reflect a uniform trend for all the countries considered: whereas Belgium registers a $55.84 \%$ reduction in the income derived from ecotaxes on water and wastewater over this period, Spain reports a five-fold increase.

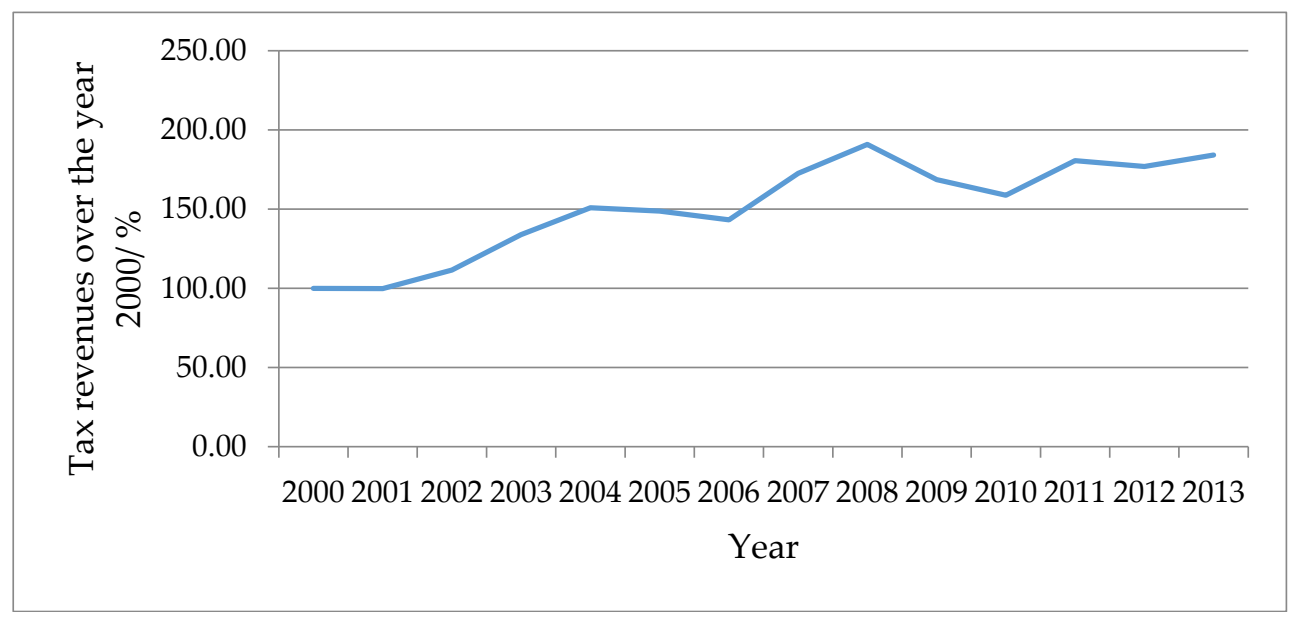

Figure 1. Evolution of revenue from environmental taxes on water and wastewater in 13 EU countries between 2000 and 2013. Source: [43].

The range of different criteria within the EU, both in 2000 and in 2013, explains the substantial differences in the tax burden on wastewater from country to country. Among the economies analysed, the Netherlands has the highest tax burden, collecting tax revenues of \$0.96 in 2013 for each cubic meter of waste water discharged. It is followed by France, Slovenia, Denmark, Hungary and Belgium. The latter, contrary to the general trend, has reduced the taxes levied in recent years. All the other countries have a very low tax burden, below $\$ 0.1 / \mathrm{m}^{3}$, falling to almost zero in Sweden and the United Kingdom, thus preventing the negative externality from being internalized.

The environmental health status of water is quantified by means of the environmental performance index (EPI) for water, which ranks countries according to conditions of access to water and sanitation [39]. This variable presents a very high average value, above 98.1 and a low coefficient of variation, indicating that the situation is similar in the different countries under study. In 2000, Estonia registers the smallest value for this indicator, at 90.90, while the other values range between that of Estonia (97.53) and Belgium (99.68). Thirteen years later, Spain has a value of 99.92, indicating relatively better conditions, followed by the Slovak Republic and Denmark, which have a value of 99.76. Hungary ranks last, with a value of 95.11.

The population's hygiene habits as well as their production and leisure activities affect the demand for water, and this demand is negatively affected by the establishment of taxes $[13,14]$. The appropriate management of water resources requires the implementation of different types of actions to prevent these resources from being wasted. Overall, such actions carried out in the countries under analysis have resulted in a $15.83 \%$ reduction in the total annual wastewater discharged per inhabitant between 2000 and 2013, falling to less than $1300 \mathrm{~m}^{3}$ /inhabitant for the total sample of countries. Contrary to this trend, however, three countries have registered an increase in the amount of wastewater discharged in this period: Estonia, France and Hungary. In absolute terms, the volume of discharges reported by countries differs widely, as evidenced by the high value for the coefficient of variation of the variable. Estonia and Spain register the highest volumes of wastewater per inhabitant per year, consistently over $193 \mathrm{~m}^{3}$. At the opposite extreme is Hungary, lying below $22 \mathrm{~m}^{3}$ per inhabitant per year. France, the United Kingdom and Sweden lie between these two extremes, with values ranging between 55 and $76 \mathrm{~m}^{3}$ /inhabitant/year. 
The HDI approximates the level of progress achieved by a country in three basic dimensions: life expectancy, access to education and income level. As such, it is generally incorporated in the design of composite sustainable development indicators [46]. As expected, given the economic area to which the analysed countries belong, they all have a high HDI, with values ranging from 0.76 for the Slovak Republic in 2000 to 0.92 registered by Denmark in 2013. In this period, all the economies manage to increase their HDI values.

The per capita expenditure that each country devotes to protecting the environment provides an approximation to the responsibility assumed by its society to guarantee the good status of its ecosystems [11,23-25]. Table 3 shows an average per capita expenditure on environmental protection activities of $\$ 116.33$ for the period 2000 to 2013 . However, the countries present a surprisingly wide range of expenditure, resulting in a high coefficient of variation for this variable. With the exception of Hungary, the Netherlands and Portugal, the per capita resources allocated to the protection of the natural environment follow a growing trend. The observed increases range from $850.08 \%$ in the Slovak Republic, almost 300\% in the Czech Republic to a minimal 5.02\% in Denmark. The Netherlands is the economy that most generously finances environmental protection, presenting per capita resources of $\$ 465.48$ at the beginning of the 21st century. Some way off with an average of more than $\$ 190$, are the United Kingdom, Belgium and Denmark, ranging from $\$ 150$ to $\$ 170$, depending on the years. The average expenditure by France, Portugal and Sweden ranges between $\$ 90$ and $\$ 110$ per inhabitant per year. Well below these values comes Spain, with an average amount of $\$ 45.36$, along with three Eastern European countries-the Czech Republic, the Slovak Republic and Slovenia-which have increased their spending considerably in these years. The countries with the lowest annual expenditure per inhabitant are Hungary and Estonia.

Ecotaxes represent an attempt to influence the polluting behaviour of economic agents and to actively protect ecosystems, both land-based and aquatic [29,47]. In the 13 countries under study, tax revenues directed towards the protection of the natural environment have maintained an upward trend, increasing in value by $77.16 \%$ in the period analysed. In all cases, the amount collected has increased in absolute terms, with increases of over $100 \%$ in the Czech Republic, Estonia, Hungary, the Netherlands, the Slovak Republic, Slovenia and Spain. This evolution, however, coincides with changes in the total tax revenues collected, resulting in a relative reduction in the weight of ecotaxes in countries' total tax revenues. In fact, in 2013 only the Czech Republic, Estonia, Slovenia and, to a lesser extent, Sweden, recorded higher percentages than in 2000. In all the other countries, the tax revenues collected for the protection of the environment represent a relatively smaller share of total tax revenues.

The dummy variables allow us to examine two institutional factors that can influence the tax burden on wastewater discharges. On the one hand, we focus on the obligation to comply with the requirements established by the WFD of 2000, which was not implemented in the Czech Republic, Estonia, Slovakia, Slovenia or Hungary until their incorporation into the EU in 2004 [43]. On the other hand, we look at public commitment to environmental issues in each country, evaluated through the support for green political movements $[34,36]$. The available information on this variable enables the identification of two groups of countries: those that have had representatives from green parties in the European Parliament since the 2004 elections, such as Belgium, Denmark, France, the Netherlands, Spain, Sweden and the United Kingdom; and the other countries, which have never had any significant representation from green parties.

\subsection{Panel Data Analysis}

The results of the estimations are summarized in Table 4, and we focus our discussion on FGLS, as the most refined model. Data from 13 countries have been used as cross-sectional variables, for the period 2000 to 2013, with a total of 182 observations. The standard error is very small in all cases, indicating a great accuracy of the estimation. 
Table 4. Panel Data Estimates.

\begin{tabular}{|c|c|c|c|c|c|c|}
\hline & $\ln T a x b$ & Coefficient & $p$-Value & Standard Error & Observations & Number of Countries \\
\hline \multirow{8}{*}{ FGLS } & $\operatorname{lnEPIw}$ & $16.23689 * * *$ & 0.000 & 1.539812 & \multirow{8}{*}{182} & \multirow{8}{*}{13} \\
\hline & $\operatorname{lnDiscpc}$ & $-0.5051688^{* * *}$ & 0.000 & 0.0911162 & & \\
\hline & $\operatorname{lnHDI}$ & $12.44003^{* * *}$ & 0.000 & 1.360553 & & \\
\hline & WFD & 0.0828205 & 0.316 & 0.0825301 & & \\
\hline & $\ln E x p c$ & $1.064694^{* * *}$ & 0.000 & 0.0423755 & & \\
\hline & $\ln W \operatorname{tax}$ & $1.542214^{* * *}$ & 0.000 & 0.1513328 & & \\
\hline & Grparty & 0.0217168 * & 0.063 & 0.0116626 & & \\
\hline & Constant & $-81.30265^{* * *}$ & 0.000 & 6.756378 & & \\
\hline
\end{tabular}

First, the model is estimated with pooled data (pooled OLS) and with random effects, comparing the two. OLS is the first model, where the temporal and spatial dimensions are removed such that the independent term, $\alpha$, referring to the effect of unknown, unobserved variables, is assumed to be fixed in time and constant for all countries; hence the sub-indices are eliminated. However, it is reasonable to assume that this term differs temporally and geographically. In the model with random effects, $\alpha_{i}$ is used as a random variable with a mean value and random deviation, determining the random effects model. In order to decide which is better-the pooled data model or the random effects model-the Breusch-Pagan Lagrangian Multiplier Test is performed, rejecting the null hypothesis that there is no variation across countries. Thus, at this stage of the process, the second model is chosen. Then, the estimation is carried out with fixed effects. It is possible that the variation across countries is not random but constant, and each random deviation must be estimated, which is the fixed effects approach. The Hausman test is used to compare the fixed and random effects models without time dummies, rejecting the fixed effects model. A series of tests are then performed to control for autocorrelation or first-order serial correlation (Wooldridge test; this occurs when the errors $e_{i t}$ are not independent with respect to time). The results of the Wooldridge test confirm the existence of autocorrelation problems, which have to be corrected. A first-order autoregressive term (AR-1) is thus introduced into the fixed effects model with a time effect, which is called the two-way AR-1 model. We also test for groupwise heteroskedasticity (using the modified Wald test; this occurs when the error variance is not constant across cross-sectional units) and contemporaneous correlation (the Breusch-Pagan for cross-sectional independence; this occurs when observations of certain units are correlated with observations of other units in the same time period), the results of which confirm that there is heteroskedasticity in the data, as well as contemporaneous correlation.

All these problems, which are fairly common in social sciences research, can be solved by means of the Prais-Winsten transformation, which is a variant of the feasible generalized least squares method (FGLS), or with panel-corrected standard errors (PCSE). The procedure used in this study is FGLS (PCSE is recommended for fixed effects models, while FGLS is recommended for random effects [48]), which assumes that there is AR-1 autocorrelation within the panels and that the coefficients of this process are specific to each group. It also assumes that the residuals are by default heteroskedastic.

The greatest effect in percentage terms corresponds to the environmental health status of water variable (a 1\%-increase in this variable corresponds to an increase of $16.24 \%$ in the tax burden on wastewater discharges) and the Human Development Index variable (a 1\%-increase in this variable corresponds to an increase of $12.44 \%$ in the tax burden on wastewater discharges), both of which are significant at the $1 \%$ level, confirming a positive relationship, and thus verifying hypotheses 1 and $3[7,13,14,18]$. Therefore, countries with a high EPI for water and a high level of economic and social development, in terms of per capita income and citizens' educational level and health conditions, are those that report a greater tax burden on wastewater discharges.

The proposed model also confirms the inverse relationship between wastewater discharges and the tax burden, as explained by hypothesis $2[13,14]$. The countries with lower volumes of wastewater discharged per capita and access to appropriate sanitation infrastructure are those that report a greater 
tax burden on discharges. The results obtained here confirm the effectiveness of tax instruments as a mechanism for ensuring better environmental conditions [5]. Furthermore, the data corroborate the definitive nature of tax revenues from water and wastewater in the countries under study.

Also of note are the sign and level of significance of the variable representing public support for green parties, confirming hypothesis $7[34,36]$. The pressure exerted by these parties to protect water ecosystems has a direct effect on the taxes levied on the economic agents responsible for pollution. These results are in line with the conclusions drawn in a study based on data from 21 OECD countries [36]. The presence of Members of the European Parliament from green political parties in a position to influence government actions has a direct effect on the development of pollution control measures, such as ecotaxes [42]. These measures shape the behaviour of citizens and companies and encourage the conservation of the natural environment.

Finally, other significant variables are the weight of environmental taxation in the national tax structure and per capita public expenditure on environmental protection, both of which show a direct relationship with the tax burden on wastewater discharges, as put forward in hypotheses 5 and $6[11,18,23-25,29]$. The variable capturing the entry into force of the WFD is not, however, significant.

Although the results obtained should be interpreted with caution, due to the level of aggregation of the statistical information used, the empirical analysis allows us to affirm that ecotaxes are crucial to improving human development conditions and the environmental health status of water. Such instruments encourage a responsible use of this natural resource, which is essential for human life. Therefore, for the group of countries analysed, this study confirms the persuasive effect of taxes levied on the polluting activity of economic agents when discharging wastewater.

\section{Conclusions}

In this paper, we have tested the relationship between the tax burden on wastewater and seven influential factors identified in the literature, by carrying out an analysis of $13 \mathrm{EU}$ member countries. The main objective of our study was to test the hypotheses and offer empirical evidence regarding the key factors that affect the tax burden on wastewater discharges in European countries. The analysis carried out above shows that the income from ecotaxes on water and wastewater has been growing in recent years, although there is not a uniform tax strategy in all the European countries under study. Quite the contrary, in fact: in 2013 there were still notable differences, both in relation to the types of taxes used to internalize the environmental cost of the wastewater discharges and the value of the applied tax. The Netherlands has the highest tax burden on discharges $\left(\$ 0.96 / \mathrm{m}^{3}\right)$, and Sweden the lowest. The results of the panel data analysis allow us to verify the hypotheses, and thus to conclude that all the variables studied are determinants of the tax burden on wastewater discharges, with the exception of the WFD implementation. Moreover, all the variables display the expected relationship. In this sense, the most influential variables are the level of environmental health status of water and the HDI, which both have a direct relationship with the main variable and are both significant at $1 \%$. The environmental health status of water has the greatest effect in percentage terms, with an increase of $16.24 \%$ in the tax burden on wastewater discharges resulting from a $1 \%$-increase in this variable, while a $1 \%$-increase in the HDI variable produces a $12.44 \%$ change in the dependent variable.

The interpretation of the proposed model results depends on the availability of statistical information for the countries analysed and the different variables considered, which could be expanded in future investigations if more complete data become available. Nevertheless, the model examines the main determinants of tax revenues linked to the discharge of water effluents, focusing on a set of developed countries displaying a concern for the protection of the natural environment. As stated in the OECD proposal [49], the United Nations Environment Programme [50] and the EU 2020 strategy [51], countries must work to promote economic growth and ensure that natural assets continue to provide the environmental resources and services that form the basis of human wellbeing, thus enabling a higher quality of life and greater productivity. This may entail the use of taxes levied on actions that are harmful to the natural environment. 
Looking ahead, it is worth bearing in mind the need for resources allocated to the public sector to finance activities aimed at ensuring a high-quality water environment. Meeting these financial needs should be directly linked to a greater tax burden on wastewater discharges, given that the proposed fiscal consolidation in EU states limits the availability of resources for constructing new infrastructure. This situation requires enhanced management transparency on the part of public administrations so that citizens-the taxpayers - can see how their tax contributions help improve the conditions of the natural environment.

Author Contributions: Encarnación Moral Pajares and Isabel María Román Sánchez gave the idea and conceived the framework; Encarnación Moral Pajares analysed the data; Leticia Gallego Valero implemented the panel data model; and Encarnación Moral Pajares and Leticia Gallego Valero wrote the paper.

Conflicts of Interest: The authors declare no conflict of interest.

\section{References}

1. United Nations (UN). Wastewater: The Resource Wasted. United Nations Global Report on Water Resources Development 2017; United Nations: Paris, France, 2017.

2. Sevik, H.; Cetin, M. Effects of water stress on seed germination for select landscape plants. Polish J. Environ. Stud. 2015, 24, 689-693. [CrossRef]

3. Yigit, N.; Sevik, H.; Cetin, M.; Kaya, N. Determination of the Effect of Drought Stress on the Seed Germination in Some Plant Species. Available online: https://www.intechopen.com/books/water-stress-in-plants/ determination-of-the-effect-of-drought-stress-on-the-seed-germination-in-some-plant-species (accessed on 3 January 2018).

4. Organization for Economic Co-Operation and Development (OECD). Water Quality and Agriculture: Meeting the Policy Challenge; OECD Studies on Water; IWA Publishing: London, UK, 2012.

5. Ortiz, E.J. La experiencia de Holanda y Alemania en el uso de cargos por vertimientos de aguas residuales como instrumento para el control de la contaminación hídrica. Elementos para decidir los parámetros en consideración. Econ. Desarro. 2005, 4, 55-87.

6. Glachant, M. The political economy of water effluent charges in France: why are rates kept low? Eur. J. Law Econ. 2002, 14, 27-43. [CrossRef]

7. Dryzek, J.S. The Politics of the Earth: Environmental Discourses; Oxford University Press: Oxford, UK, 2013.

8. Borrego-Marín, M.M.; Gutiérrez-Martín, C.; Berbel, J. Estimation of cost recovery ratio for water services based on the System of Environmental-Economic Accounting for Water. Water Res. Manag. 2016, 30, 767-783. [CrossRef]

9. Udias, A.; Malagò, A.; Pastori, M.; Vigiak, O.; Reynaud, A.; Elorza, FJ.; Bouraoui, F. Identifying Efficient Nitrate Reduction Strategies in the Upper Danube. Water 2016, 8, 371. [CrossRef]

10. Lindström, A.; Audun, R. Whose Hydropower? From Conflictual Management into an Era of Reconciling Environmental Concerns; a Retake of Hydropower Governance towards Win-Win Solutions? Sustainability 2017, 9, 1262.

11. Zárate, A.; Valles, J.; Trueba, C. Descentralización Fiscal y Tributación Ambiental: El Caso del Agua en España; Instituto de Estudios Fiscales: Madrid, Spain, 2007.

12. Panayotou, T. Instruments of Change: Motivating and Financing Sustainable Development; Routledge: London, UK, 2013.

13. Barbier, E.B.; Markandya, A. A New Blueprint for a Green Economy; Routledge: London, UK, 2013.

14. Organization for Economic Co-Operation and Development (OECD). Towards Green Growth? Tracking Progress; Organization for Economic Co-Operation and Development: Paris, France, 2015.

15. Riera, P. Manual de Economía Ambiental y de los Recursos Naturales; Paraninfo: Madrid, Spain, 2005.

16. Román, I.M.; Carra, I.; Sanchez, J.A. El uso sostenible del agua: Tributos medioambientales y nuevos procesos de descontaminación mediante energías renovables. Estud. Econ. Apl. 2013, 31, 197-216.

17. OECD/EEA. Database on Instruments Used for Environmental Policy and Natural Resources Management. Available online: http:/ / www2.oecd.org/ecoinst/queries/ (accessed on 1 March 2017).

18. Gelissen, J. Explaining popular support for environmental protection a multilevel analysis of 50 nations. Environ. Behav. 2007, 39, 392-415. [CrossRef] 
19. Bye, B. Taxation, unemployment, and growth: Dynamic welfare effects of green policies. J. Environ. Econ. Manag. 2002, 43, 1-19. [CrossRef]

20. Fiorino, D.J. Explaining national environmental performance: approaches, evidence, and implications. Policy Sci. 2011, 44, 367-389. [CrossRef]

21. Vergès, J.F. Servicios de Agua Potable y Alcantarillado: Lecciones de las Experiencias de Alemania, Francia e Inglaterra; United Nations: Santiago de Chile, Chile, 2010.

22. Rosenstock, M. Environmental Taxation within the European Union. Cyprus Econ. Policy Rev. 2014, 8, 113-123.

23. Molinos-Senante, M.; Hernández-Sancho, F.; Sala-Garrido, R. Economic feasibility study for wastewater treatment: A cost-benefit analysis. Sci. Total Environ. 2010, 408, 4396-4402. [CrossRef] [PubMed]

24. Román-Sánchez, I.M.; Carra, I.; Sánchez-Pérez, J.A. Promoting environmental technology using sanitary tax: the case of agro-food industrial wastewater in Spain. Environ. Eng. Manag. J. 2014, 13, 961-969.

25. Molinos-Senante, M.; Hernández-Sancho, F.; Sala-Garrido, R. Cost-benefit analysis of water-reuse projects for environmental purposes: A case study for Spanish wastewater treatment plants. J. Environ. Manag. 2011, 92, 3091-3097. [CrossRef] [PubMed]

26. Bixio, D.; Thoeye, C.; De Koning, J.; Joksimovic, D.; Savic, D.; Wintgens, T.; Melin, T. Wastewater reuse in Europe. Desalination 2006, 187, 89-101. [CrossRef]

27. Angelakis, A.N.; Durham, B. Water recycling and reuse in EUREAU countries: Trends and challenges. Desalination 2008, 218, 3-12. [CrossRef]

28. Jiménez, B.; Asano, T. Water reclamation and reuse around the world. In Water Reuse: An International Survey of Current Practice, Issues and Needs; International Water Association: London, UK, 2008; pp. 3-26.

29. Gago, A.; Labandeira, X.; López-Otero, X. A panorama on energy taxes and green tax reforms. Hacienda Pública Esp. 2014, 208, 145-190. [CrossRef]

30. Bird, R.M.; Martinez-Vazquez, J.; Torgler, B. Tax effort in developing countries and high income countries: The impact of corruption, voice and accountability. Econ. Anal. Policy 2008, 38, 55-71. [CrossRef]

31. Molina-Morales, A.; Amate-Fortes, I.; Guarnido-Rueda, A. Economic and institutional determinants in fiscal pressure: An application to the European case. J. Econ. Issues 2011, 45, 573-592. [CrossRef]

32. García, M.D.; Torgler, B. Impuestos y protección medioambiental: preferencias individuales en Europa. Rev. Econ. Apl. 2010, 18, 107-132.

33. Klok, J.; Larsen, A.; Dahl, A.; Hansen, K. Ecological Tax Reform in Denmark: History and social acceptability. Energy Policy 2006, 34, 905-916. [CrossRef]

34. Kenny, L.W.; Winer, S.L. Tax systems in the world: An empirical investigation into the importance of tax bases, administration costs, scale and political regime. Int. Tax Public Financ. 2006, 13, 181-215. [CrossRef]

35. Benito, B.; Bastida, F.; Muñoz, M.J. Factores explicativos de la presión fiscal municipal. Rev. Contab. 2010, 13, 239-283. [CrossRef]

36. Neumayer, E. Are left-wing party strength and corporatism good for the environment? Evidence from panel analysis of air pollution in OECD countries. Ecol. Econ. 2003, 45, 203-220. [CrossRef]

37. Organization for Economic Co-Operation and Development (OECD). Water Pricing: Current Practices and Recent Trends; Organization for Economic Co-Operation and Development: Paris, France, 1999.

38. Boscheck, R.; Clifton, J.C.; Díaz-Fuentes, D.; Oelmann, M.; Czichy, C.; Alessi, M.; Treyer, S.; Wright, J.; Cave, M. The regulation of water services in the EU. Intereconomics 2013, 48, 136-158. [CrossRef]

39. Yale University. Global Metrics for the Environment. Environmental Performance Index. Available online: http:/ / www.epi.yale.edu (accessed on 1 March 2017).

40. AQUASTAT. FAO's Information System on Water and Agriculture Database. Available online: http:/ / www.fao.org/nr/water/aquastat/data/query/index.html?lang=en (accessed on 1 March 2017).

41. United Nations Development Programme (UNPD). Datos Sobre el Desarrollo Humano. Available online: http:/ / hdr.undp.org/es/data (accessed on 1 March 2017).

42. Parliament and Council of the European Union. Directive 2000/60/EC, of 23 October 2000, Establishing a Framework for Community Action in the Field of Water Policy; DO L, 327; Parliament and Council of the European Union: Brussels, Belgium, 2000.

43. Organization for Economic Co-Operation and Development (OECD). Statistics on the Environment. Available online: http:/ / stats.oecd.org/ (accessed on 1 March 2017). 
44. European Parliament. European Election Results. Available online: http://www.europarl.europa.eu/meps / es/hemicycle.html (accessed on 1/5/2017).

45. Baltagi, B.H. Econometric Analysis of Panel Data, 3rd ed.; John Wiley \& Sons: New York, NY, USA, 2005.

46. Soto, H.; Schuschny, A.R. Guía Metodológica: Diseño de Indicadores Compuestos de Desarrollo Sostenible; Cepal: Santiago, Chile, 2009.

47. Bosquet, B. Environmental tax reform: Does it work? A survey of the empirical evidence. Ecol. Econ. 2000, 34, 19-32. [CrossRef]

48. Andreß, H.J.; Golsch, K.; Schmidt, A.W. How to Do Your Own Panel Analysis. In Applied Panel Data Analysis for Economic and Social Surveys; Springer: Berlin/Heidelberg, Germany, 2013; pp. 287-292.

49. Organization for Economic Co-Operation and Development (OECD). Towards Green Growth; Monitoring Progress; Organization for Economic Co-Operation and Development: Paris, France, 2011.

50. The United Nations Environment Programme (UNEP). Towards a Green Economy: Pathways to Sustainable Development and Poverty Eradication; United Nations Environment Programme: Nairobi, Kenya, 2011.

51. European Commission. Europe 2020: A Strategy for Smart, Sustainable and Inclusive Growth; European Commission: Brussels, Belgium, 2010.

(C) 2018 by the authors. Licensee MDPI, Basel, Switzerland. This article is an open access article distributed under the terms and conditions of the Creative Commons Attribution (CC BY) license (http:/ / creativecommons.org/licenses/by/4.0/). 